\title{
ROMANTISMO, MÍSTICA E ESCATOLOGIA POLÍTICA
}

FRANZ JOSEF BRÜSEKE

Vertentes filosóficas, políticas ou estéticas que contestaram os paradigmas centrais da modernidade são tradicionalmente percebidas como externas à própria modernidade. Neste sentido, estão sendo apresentadas como se fossem restos de um mundo a ser superado ou, no mínimo, como resíduos dos velhos tempos condenados pelo progresso histórico ao seu fim inevitável. Também encontramos externalizações de movimentos alternativos à modernidade na direção do futuro, onde elas tornam-se utópicas ou sonhos políticos irrealizáveis. A dupla externalização (Klinger, 1995) das alternativas à modernidade técnica (Brüseke, 2002a), uma vez na direção do passado e outra vez na direção do futuro é, na verdade, resultado da própria ideologia técnica e científica (Habermas, 1968/1994) que não suporta posições que contestam a universalidade do processo de racionalização ocidental (Weber, 1904/1981). Queremos falar sobre aquilo que a própria ideologia modernizante denuncia como um irracionalismo antimoderno que, todavia, acompanha esta modernidade desde seus primórdios e recebe dela, paradoxalmente, impulsos aceleradores. Apresentar o romantismo, a mística e a escatologia, ainda nas suas formas decadentes, como acompanhantes fiéis da modernidade técnica significa, também, entendê-los como fenômenos históricos que não entregaram, de antemão, as alternativas imaginárias ao mito da máquina (Mumford, 1966/1977); mito evocado pelos técnicos de uma modernidade que quer esquecer as dimensões do Ser e da existência humana que transbordam o fatual e o mundo manipulável (Heidegger, 1954/1994).

\section{OS SENTIMENTOS NO MODELO RACIONALIZANTE}

Segundo Weber, existem na sociedade moderna três esferas que, em sua totalidade, representam a racionalidade moderna. São elas: (1) a 
esfera da racionalidade cognitiva presente na ciência e na técnica, (2) a esfera da racionalidade evaluativa como aparece no direito e na ética e (3) a racionalidade expressiva e estética, virulenta na arte e nas relações amorosas. No processo da racionalização crescente, ganham essas três esferas cada vez mais autonomia, devido a um processo acentuado de diferenciação. A divisão entre o público e o privado é fruto dessa diferenciação que delega a racionalidade expressiva e estética praticamente ao privado, regido pela subjetividade e suas necessidades expressivas. Até certo ponto, parece curioso chamar a racionalidade estética e expressiva ainda de racionalidade, pois ela possui, já para Weber, fortes ingredientes antiracionais e afetivos. Pois exatamente devido a essa característica esta esfera torna-se, sob condições modernas, um refúgio do indivíduo atormentado pelas pressões racionalizantes que dominam a vida pública.

A chamada racionalidade estética-expressiva faz parte do complexo da racionalidade moderna. É, então, um fenômeno moderno. Não obstante, possui a racionalidade dos fins econômicos e a racionalidade de valores, presentes no moderno Estado racional e em seu sistema jurídico e administrativo, uma força que delega a terceira esfera, estética-expressiva, a uma posição inferior, exposta às incursões racionalizantes oriundas da primeira e segunda esferas. Daí surge a visão da gaiola de ferro como destino do mundo; expressão de Weber que simboliza a supremacia crescente e definitiva da racionalidade científica e técnica sobre o mundo da vida. Habermas, nos passos de Weber, constata igualmente uma colonização desse mundo pelos sistemas econômicos e administrativos e tenta fortalecer processos comunicativos os quais ainda estão fora de seu alcance.

No contexto de nossa reflexão sobre o romântico, é importante perceber que Weber situa a subjetividade, com seus fortes traços não racionais, dentro do complexo da racionalidade moderna. Para ele, a subjetividade autonôma é produto da modernidade ou pelo menos uma das suas características mais marcantes. Desta maneira, a visão weberiana evita a externalização das irracionalidades de qualquer espécie, que emanam da subjetividade moderna; subjetividade que é autônoma e ao mesmo tempo vítima da corrosão de valores capazes de garantir um sentido objetivo. O sentido subjetivo é exatamente o ponto de partida da sociologia weberiana, que quer entender tanto o que um ator pretende quanto o sentido que ele atribui à sua ação. Lembramos que Weber distingue, em Economia e Sociedade, várias possíveis determinações de uma ação; a ação pode ser motivada por uma racionalidade de fins, por uma racionalidade de valores, por forma afetiva, e por tradição (Weber, 1922/1985:12). É curioso que a sensibilidade de Weber 
pelo sentido subjetivo leva-o para a construção de uma sociologia que nos apresenta a perspectiva da sociedade moderna dominada pela grande dinâmica econômica e administrativa, onde esse sentido subjetivo parece estar esmagado pela objetividade. Assistimos então a passagem, na sociologia weberiana, de uma teoria da ação social para uma teoria da ordem social. Essa passagem é observada por Alan Dawe também na obra de outros autores (Dawe, 1978/1980). Entende-se agora porque Habermas, ciente ou não disso, entrega, sem grande cerimônia, o sistema econômico e o sistema administrativo a uma racionalidade inacessível à ação comunicativa; as consequências da herança weberiana são evidentes.

Se voltarmos à figura argumentativa inicial de Weber, que nos fala das três esferas de racionalidades, podemos agora identificar que o autor, desde o início, não lhes deu igual peso; como no caso da determinação da ação subjetiva, no processo histórico predomina, cada vez mais, a racionalidade de fins e uma racionalidade de valores que dá sustento às necessidades dos sistemas econômico e administrativo. A subjetividade fica encarcerada no subsolo da modernidade técnica, celebrando sua autonomia com meios estéticos e expressivos inéditos. Encontramos neste souterain, que parece abrigar o subconsciente da modernidade, as irracionalidades de qualquer espécie, para usar mais uma vez essa expressão cara a Weber: as paixões que obrigam a matar por amor, o amor que torna doce a escravidão, a fantasia que transforma as paredes cinzas do subsolo em vitrines da alma do mundo e encontramos também o nosso ser romântico, na busca de uma flor azul (Müller-Funk, 2000).

A esfera da modernidade estética-expressiva - que a própria modernidade gerou - tem uma função extraordinária no funcionamento das esferas regidas pela racionalidade técnica e científica. Mas até a submissão à ética de responsabilidade, seguindo a racionalidade de valores, precisa, de vez em quando, de uma válvula de escape para garantir seu funcionamento contínuo. Assim, no conjunto das três racionalidades acima descritas, a racionalidade expressiva e estética possui essa funcionalidade extraordinária devido à compensação das frustrações que a própria modernidade técnica representa para os indivíduos. Surpreende ainda que o romantismo tenha surgido exatamente no fim do século dezoito, do século das luzes, e no início da industrialização? Nesta fase (1790-1840) as pessoas mais sensíveis viveram uma experiência de contraste em relação às grandes mudanças provocadas no processo da modernização; assistiram ao advento dos sistemas fechados de pensamento racional e começaram a fugir para um lugar que lhes parecia mais atraente. Este lugar era a própria 
alma; alma que tremia frente às maravilhas da natureza e do jogo perturbador entre as luzes da razão e as sombras do inexplicável. Pois essa fuga para o interior era ao mesmo tempo um despertar e, assim, um ataque. Os gritos histéricos dos racionalistas não deixaram dúvidas de que os românticos tocaram em um ponto sensível da consciência moderna.

\section{O ROMANTISMO}

A palavra romântico surgiu no fim do século dezoito e possuía, inicialmente, vários significados. Denominava, por um lado, as línguas de origem romana: francês, espanhol, português, italiano e romeno; línguas que até hoje são estudadas na faculdade de Romanistik, na Alemanha. Romântica era também a literatura antiga dessas línguas; era escrita em medidas rítmicas não-clássicas e tinha para o público alemão da época traços fantásticos, estranhos e maravilhosos, isto é, românticos. Como romantismo denominamos, também, uma época literária entre aproximadamente 1790 e 1830 e em contato ambivalente com a época clássica (1786-1805). Era a década da cooperação de Goethe e Schiller em Weimar e a fase do Biedermeier, entre 1815 e 1850.

Podemos constatar uma forte resistência dos motivos românticos tanto nas produções literárias e filosóficas subseqüentes a esses exemplos, como no folclore e no imaginário popular.

O romantismo, apesar de seu auge na Alemanha, é um movimento cultural europeu, com influência também nas colônias européias da época. Possuiu vários precursores e esteve ligado a vertentes filosóficas, literárias e artísticas que apresentavam, antecipadamente, motivos românticos em contextos iluministas e clássicos. São pré-românticos, na França, Diderot e Rousseau e, na Inglaterra, Young, Shaftesbury, Gray e Macpherson. Também a cultivação dos sentimentos, no pietismo, preparou o chão, ou melhor dizendo, a alma para os sentimentos românticos posteriores. Autores clássicos, como o já mencionado Goethe, que se voltaram na idade madura contra o movimento romântico, contribuíram para seu surgimento. Podemos interpretar o culto do gênio e da subjetividade sensível que encontramos no Jovem Werther e em geral na literatura do Sturm und Drang como momentos românticos. Cedo vincula-se o romantismo com o folclore literário. Já em Herder encontramos a valorização da poesia popular, tão característica da última fase do romantismo com seus grandes colecionadores de lendas, como os irmãos 
Grimm, que documentaram de forma escrita o que foi até então transmitido oralmente de geração para geração. A volta às raízes populares e históricas era expressão da saudade romântica de encontrar a fonte pura e original da arte e da cultura. Não surpreende, então, que o romantismo, superando o iluminismo num movimento de busca para trás, descobrisse a idade média e sua mística, considerada obscura e incompreensível pelos autores racionalistas. A transformação do narrado em literatura contribuiu, por sua vez, para um processo de cientificização e racionalização da narrativa popular e impulsionou o desenvolvimento da germanística como ciência da literatura e disciplina universitária; um efeito racionalizante não intencionado pelos românticos.

Em geral, a história da literatura na Alemanha distingue três fases do romantismo. Na primeira fase, até 1802, comumente denominada romantismo inicial, destacam-se as cidades de Jena e de Berlim, onde autores como Schlegel celebram o espírito criador e a autoconsciência do $E u$ cuja fantasia está movida pela saudade do infinito. Com uma postura que podemos chamar hoje de antipositivista, o romantismo defende uma percepção do infinito que não se deixa conceber em formas definidas e limitadas. Na segunda fase, tendo Heidelberg e Berlim como centro, o romantismo apresenta uma completa visão de mundo, onde entende o Ser como um eterno emergir e devir, e o indivíduo como expressão do ilimitado. A filosofia romântica dessa época possuia fortes traços especulativos, como se observa em Schelling e Schleiermacher, Oken e Steffens. Estes autores estavam atentos ao pré-consciente ou subconsciente e chamavam atenção para o lado escuro da existência humana e para um resíduo inexplicável do Ser, inacessível à razão. A última fase do romantismo, com sua já mencionada valorização da arte popular, aflora em Dresden, Munique, Viena e Suábia, onde destaca-se a aliança dos poetas. $\mathrm{O}$ romantismo literário alemão influenciou fortemente os movimentos românticos na França, com Chateaubriand, Victor Hugo, Lamartine e George Sand; na Inglaterra, com Wordsworth, Lord Byron, J. Keats e W. Scott; na Italia com Manzoni, Leopardi e Foscolo; na Espanha com Zorilla e Espronceda y Delgado; na Escandinávia com Andersen e Tegnér e na Rússia com Puschkin e Lermontow, entre muitos outros. Encontramos também formas artísticas de um romantismo banalizado, as quais manifestam demandas subjetivas não atendidas pela modernidade técnica até os dias de hoje.

Milan Kundera (1990) faz, em seu livro A Imortalidade, a seguinte observação: 
A civilização européia é supostamente fundamentada na razão. Mas também poderíamos dizer que a Europa é uma civilização do sentimento; ela deu origem ao tipo humano que eu gostaria de chamar o homem sentimental: homo sentimentalis [...] É preciso definir o homem sentimental não como uma pessoa que experimenta sentimentos [...] mas como uma pessoa que os valorizou. Desde que o sentimento seja considerado valor, todo mundo quer experimentálo; e como todos nós temos orgulho de nossos valores, é grande a tentação de exibir nossos sentimentos. [...] Do momento que queremos experimentá-lo [...] o sentimento não é mais sentimento, mas imitação de sentimento, sua exibição. Aquilo que geralmente chamamos histeria. É por isso que o homo sentimentalis (em outras palavras, aquele que instituiu o sentimento como valor) é na realidade idêntico ao homo hystericus. (Kundera, 1990:190/191)

Sobre sentimentos falam-nos os mais antigos documentos; assim, sabemos dos sentimentos de fidelidade e de honra capazes de conduzir um cavalheiro medieval à morte em defesa do seu senhor ou a matar o próprio filho, como relata o Hildebrandslied anotado por dois monges de Fulda entre 830 e 840 . Todavia, são esses sentimentos, exatamente por causa de sua intensidade que não deixa escolha, mais internalizações emotivas de prescrições socias do que sentimentos, no sentido comum de hoje. O homo sentimentalis, ao qual Kundera se refere, começa a ganhar traços no século XII quando os trovadores e Minnesänger encantam os corações das belas moças da época. As canções dos trovadores, em geral dirigidas às damas da alta sociedade, expressam sentimentos de amor e admiração e vivem da impossibilidade de alcançar o objeto do seu desejo. A mulher amada e idealizada é inacessível para o próprio trovador. Ele, por sua vez, não insiste na realização de seus sentimentos amorosos que, freqüientemente, eram direcionados à esposa do seu senhor. Encontramos no homo sentimentalis do Minnesang, pela primeira vez, como nos parece, a valorização dos sentimentos, embora ainda em uma forma que disciplinava sua individualização plena. Já em Walther von der Vogelweide $(\sim 1170-\sim 1230)$ temos um trovador que tende a quebrar as prescrições da Minne conhecida até então. Esse direciona suas canções também a mulheres não-casadas das camadas baixas e busca, poeticamente, complementação individual dos sentimentos. Podemos dizer que esse trovador faz a ponte entre a Minne e a poesia de amor; de um amor individualizado e correspondido pela mulher. Mais tarde, Walther von der Vogelweide volta para a Minne stricto sensu e deixa para nós versos de um homem desiludido: 
Diu Welt ist ûzen schoene, wîz grüen unde rôt

Die Welt ist aussen schön, weiss, grün und rot

$O$ mundo é belo por fora branco, vermelho e verde

Und innân swarzer varwe, vinster sam der tôt.

Und innen von schwarzer Farbe, finster wie der Tod.

$E$ dentro de cor preta, e escuro como a morte.

É difícil para nós, hodiernos, entender os sentimentos dos homens e das mulheres medievais. Todavia, podemos ver como a subjetividade dos sentimentos começa se articular muito antes da manifestação do sujeito intelectual, expresso no auto-consciente Cogito ergo sum! de Descartes (1596-1650). Podemos também ver que a valorização dos sentimentos submete os mesmos a um mecanismo comunicativo que tende a afastar o sentimento de seu fundamento, que é o interior do homem. Mostrar sentimentos significa colocar seu coração na mesa de homens famintos (Wolf Biermann), significa também sentir a improbabilidade da comunicação (Niklas Luhmann, 1992) e se tornar um homo sentimentalis incompreendido pelo homo faber.

A valorização dos sentimentos leva, como afirma Kundera, à imitação do sentimento que se torna, no processo da sua valorização, inautêntico, um simulacro de si mesmo: o homo sentimentalis transformase no homo hystericus. Em parte isso acontece devido à impossibilidade da externalização da interioridade: eu posso falar sobre meus sentimentos, mas não consigo fazer que o outro sinta o que eu sinto. Todavia, a sociedade moderna vive cada vez mais da valorização da expressão desse íntimo que é o sentimento. A degradação do sentimento, sob condições modernas, à mera sensação é a base do sensacionalismo generalizado que é o ambiente preferido do homo hystericus.

Todavia remete-nos, o homem sentimental, a uma estranha dialética: na medida em que a subjetividade sentimental começa a ganhar força, desperta também o sujeito cognitivo. O homem moderno nasce, como nos parece, com uma identidade ambígua, incapaz - desde a Idade Média - de encontrar seu equilibrio. Extrapolando um lado dessa ambigüidade na direção do sentimento, valorizando-o, faz-se emergir o homo hystericus; por outro lado, a desvalorização do sentimento pelo intelecto leva ao congelamento daquilo que é próprio do homem. Falando com Walther von der Vogelweide: "Que eles não entendem, o que é amor, isto é inaceitável!" Falamos sobre dialética e esperamos uma síntese ou, pelo 
menos, um movimento da tese e da antítese que se encontram, até agora, num impasse. Para onde aponta a dialética dos sentimentos e do intelecto?

A época literária que denominamos comumente romantismo tinha viva consciência de suas próprias bases filosóficas. O romantismo desse tempo já é reflexivo, para usar um termo freqüentemente utilizado para caracterizar a modernidade dos dias atuais. Joseph Eichendorff, autor do romantismo tardio, vê as raízes do romantismo na reforma protestante que colocou o indivíduo acima do dogma e fez da emancipação da subjetividade de todas as restrições hierárquicas seu princípio máximo. Essa subjetividade alcançou de fato, em todas as manifestações estéticas do romantismo, uma valorização inédita. Também para Octavio Paz o romantismo é uma consequência do protestantismo. Através da interiorização da experiência religiosa a reforma teria criado as pré-condições para o movimento romântico.

$\mathrm{Na}$ verdade, a valorização da experiência religiosa remete, no âmbito da subjetividade, à tradição mística combatida pela teologia cristã e por sua vertente escolástica. De Bernard de Clairvaux (1091-1153) até Mestre Eckart (1260-1328) estende-se uma corrente de teólogos, acompanhados por um verdadeiro movimento popular dentro e na margem da igreja romana, que por séculos cultivaram intensamente a busca do divino dentro da própria alma. A experiência mística da unidade com Deus, a unio mistica, era uma experiência subjetiva que transbordava todos os conceitos e doutrinas teológicas. Era impossível para a igreja romana admitir uma união com o divino sem a sua intermediação, inadmissível relativizar a importância do verbo de Deus para a fé cristã e colocar a experiência do fiel no centro da fé.

A partir da teologia de Tomás de Aquino (1225-1274) - que integrava elementos da filosofia grega, principalmente de Aristóteles, que foi redescoberto pela escola de Toledo e mostrava a afinidade do verbo com o $\operatorname{logos}$ - a igreja romana conseguiu, depois de séculos de perseguição bastante casuística, conter, também teologicamente, a onda mística. O preço da racionalização da teologia no fim da Idade Média foi alto. Por um lado, a igreja romana abortou uma vertente teológica que mostrou extrema vitalidade porque conseguiu dar respostas às demandas contemporâneas referentes à experiência subjetiva da unidade e do sentido. Demandas que resultaram, já na Idade Média, do despertar da subjetividade. Por outro lado, a racionalização da teologia na escolástica preparou o chão para o desenvolvimento do pensamento científico que logo deveria tornar-se um adversário da dogmática romana maior e mais eficiente do que os próprios 
místicos. O desencantamento do mundo começa dentro da teologia cristã ... até se voltar contra ela mesma. Interessante observar que a reforma luterana, apesar de sua extrema valorização do verbo autêntico, abraçou a experiência interior de Deus, mostrando-se - estando ou não ciente disso influenciada pela tradição da mística medieval.

O romantismo passa a entender o sujeito abstrato do idealismo e do iluminismo como indivíduo. Entre aqueles que formularam a nova visão da individualidade foi Friedrich Schlegel aquele que colocou no lugar do sujeito transcendental o sujeito empírico. Cornelia Klinger diz, com razão, que o romantismo mudou a perspectiva da auto-preservação e autodeterminação, característica do iluminismo, para a idéia da auto-realização e do desdobramento dos potenciais individuais (Klinger, 1995:110); estamos assim frente à passagem para o lado expressivo do sujeito. A autonomia do Eu do romantismo é ponto de partida da racionalidade estética-expressiva que, como sabemos, completa com a racionalidade cognitiva-científica e com a racionalidade evaluativa o tripé das racionalidades de Weber. Também Georg Simmel interpreta o romantismo como fase histórica na qual acontece uma transformação do individualismo quantitativo (individualismo da singularidade, der Einzelheit) para o individualismo qualitativo (o individualismo da originalidade, da Einzigkeit) (Simmel, 1917/1970).

A descoberta da individualidade colide com categorias metafísicas de primeira grandeza. $\mathrm{O}$ absoluto, o infinito, o eterno se opõem à temporalidade individual. $\mathrm{O}$ indivíduo encontra-se frente à eternidade equipado somente com o tempo limitado. Este tempo limitado à disposição do individuo é o tempo de sua vida. O tempo da vida por sua vez é o tempo da vida do corpo individual. Descobrir a temporalidade individual significa, também, descobrir a sua corporalidade. O tempo agride o corpo e faz o romântico tremer frente ao abismo entre o eterno e o finito, sentido no fundo da sua alma. O que significa o mundo? O que significa $E u$ no mundo? Doloroso mesmo é a beleza do mundo que parece transbordar a minha vida finita, que em momentos especiais parece tocar na eternidade. Lágrimas enchem os olhos do romântico que não sabe o que significa o por quê dele ser tão triste 1 . O homo romanticus cultiva as lágrimas e mostra os seus sentimentos de forma estética. A poesia, a literatura em geral, a pintura e, em especial, a música expressam esses sentimentos. Todavia, é difícil falar do estilo romântico como podemos falar do estilo barroco, por exem-

${ }^{1}$ Heinrich Heine é influenciado pelo romantismo e, ao mesmo tempo, seu crítico mordaz. Dele são as palavras: "Eu não sei o que significa o por quê de eu ser tão triste." 
plo. O romantismo define-se mais através de um novo olhar, de um novo entendimento do homem, na sua subjetividade, e da vontade de expressar essa subjetividade. Ser romântico é mais do que uma forma de ser, é muito mais uma maneira de sentir. $\mathrm{O}$ fato desses sentimentos estarem sendo valorizados, além de serem sentidos, coloca, como Kundera nos mostrou, o homo sentimentalis ao lado do homo hystericus. Não surpreende que os sentimentos expostos por nosso romântico expõem-se freqüentemente ao ridículo ou, pelo menos, à ironia afiada de um Heinrich Heine. Em termos da crítica estética, podemos dizer: a arte romântica tem afinidade especial com o Kitsch. Ter essa afinidade, todavia, não significa ser idêntico a ele. $\mathrm{E}$ isso pode mesmo ser o segredo do romantismo, que é por muitos considerado tão irritante: o romantismo escapa de sua definição, é uma eterna busca da flor azul, é um querer e não alcançar, é uma saudade sem fim.

\section{A MÍSTICA SEM DEUS}

No final do século XIX não existe mais, para muitos autores, pensadores e poetas, o recurso de uma transcendência teologicamente entendida. Essa época assumiu o programa cognitivo das ciências modernas e foi, além do mais, convicta da supremacia da razão e do progresso inevitável do racionalismo ocidental. A transcendência tornou-se, para os cientistas dessa época, uma categoria fantasmagórica, resultado tanto da filosofia idealista como do imaginário religioso. Não obstante, surge, na margem da consciência da época, uma nova onda mística, reinterpretação da mística tradicional sob condições modernas. Assim, a experiência mística, que têm como seu cerne a união do Eu com a totalidade divina, é transferida para outros campi, principalmente para o mundo da vida desdivinizado. Também partes dele, como a sociedade ou em geral coletivos sociais, como homens singulares, ou meramente a vida, inclusive seu aspecto sexual, sofrem um carregamento místico. Mais tarde, a mística sem Deus expressa-se igualmente numa mística da ação, presente tanto nas ideologias de tipo fascista ou revolucionário como em filosofemas existencialistas. Ela aparece também no decorrer do século XX numa mística negativa que conhece a experiência mística esvaziada como pesadelo (Kafka), como absurdo (Camus, Beckett) e como grotesco (Ionesco).

A mística moderna tem na Alemanha, que sofre mais do que outros países com a crise da metafísica, um primeiro surto. Aqui começa a florir o sentimento de que a realidade, o mundo ou relevantes partes dele 
não são completamente acessíveis às ciências modernas ou à linguagem. Grandes e polêmicas críticas da linguagem (Mauthner, Wittgenstein) aparecem contemporaneamente com a relativização das certezas científicas e de suas grandezas absolutas (Einstein, Planck, Heisenberg). O ceticismo referente à razão e à linguagem acompanharam a teologia e a filosofia mística desde seus primórdios.

Para Wittgenstein, cabe à filosofia delimitar o pensável e, com isso, o impensável. Essa delimitação do pensável pode acontecer somente no campo do dizível; é, então, uma limitação do impensável a partir de dentro, através do pensável. É de suma importância, para a compreensão do pensamento de Wittgenstein, entender essa função da filosofia que é significar o indizível ao apresentar claramente o dizível.

O ilógico, quando encontrado na realidade, é resultado de impurezas na aplicação lógica do pensamento. Tanto o ilógico quanto os problemas filosóficos aparentemente insolúveis, desaparecem com a colocação correta, lógica, das questões. O ilógico que resiste é aquilo que a linguagem não alcança, é aquilo sobre o qual não posso falar, sem me tornar, também, ilógico.

"Uma proposição só pode dizer como uma coisa é, não o que ela é" (Wittgenstein, 1918/1994:151). Wittgenstein, consciente disso ou não, refere-se aqui à diferença ontológica entre Ser e Ente, entre o "como" e o "o que" das coisas. O dizível é o mundo das qualidades variadas dos fatos (dos Entes), e os fatos no espaço lógico são o mundo. Descrever como o mundo é tornou-se o empreendimento das ciências naturais, esta "descrição" consiste na compreensão da lógica interna dos fatos. A compreensão dos fatos abre o caminho na direção de sua manipulação técnica, que compõe e decompõe o seu como. Fica no escuro o que as coisas são, pois a luz que Wittgenstein joga em cima daquilo que é o caso projeta, ao mesmo tempo, a sua sombra sobre aquilo de que não podemos falar. $\mathrm{E}$ exatamente essa é a intenção do autor que, com toda razão, pode convidar, no final do seu livro, o leitor a jogar fora a escada pela qual ele subiu. Qual é a escada? O Tractatus de Wittgenstein e as três dimensões que cogita, que são: a linguagem, a realidade e a lógica.

Sentimos como o jovem Wittgenstein luta, nos últimos parágrafos do Tractatus, com o indizível. Não porque é simplesmente indizível e como tal um desafio para a linguagem; não: a finalização do Tractatus ganha dramaticidade porque o autor aproxima-se daquilo que é para ele o mais importante. Aponta na direção do excluído, perdendo-se por alguns momentos nos fragmentos que sabe ainda formular. Por que falar agora 
apressadamente sobre os mais altos valores, a ética, a estética, sobre Deus e o sentido da vida? Wittgenstein, antes de se calar por muitos anos, ainda nos diz: "O Místico não é como o mundo é, mas que ele é" (Wittgenstein, 1918/1994:278). E mais adiante: "Há por certo o inefável. Isso se mostra, é o Místico" (Wittgenstein, 1918/1994:281).

O que é dizível, o que é indizível? O que é aquilo que é indizível? Como falar sobre a experiência limite quando o indizível se mostra? No início do século XX, na arte, na música, na literatura e filosofia e também em algumas áreas das ciências exatas, como na física teórica, as melhores cabeças da Europa lutam para situar-se melhor num mundo sob o impacto da razão técnica e da fuga dos deuses. A filosofia da linguagem era somente um campo, todavia um campo privilegiado, para formular as ansiedades da modernidade.

Nietzsche, para muitos o primeiro crítico filosófico da razão moderna centrada no sujeito, tentava resolver a crise da metafísica de sua maneira. O filósofo-poeta era um ateu, como sabemos, e deixa seu Zaratustra declarar a morte de Deus. "Ele ainda não ouviu falar que Deus está morto?" diz ele depois de ter encontrado, durante sua descida da montanha, um eremita louvando ao Senhor. O primeiro profeta, esse Zaratustra, que não anuncia a chegada do Messias, mas a sua morte; um sábio que sabe da ausência de Deus. O que vai ser de um profeta sem Deus? Num impulso, que vem daquilo que está ausente, continua sendo o que é. Pois Zaratustra quer falar, para os homens, sobre algo mais, sobre algo além do homem real, sobre um homem que transcende o próprio homem.

Antes de elaborar sua obra madura, o Zaratustra, Nietzsche, no seu ambíguo furor ateu, lança mão dos deuses. Dionísio e Apolo ganham importância específica tornando-se, como princípios no pensamento de Nietzsche, dois pólos que ordenam, de certa forma, um pensar que carece, em geral, de sistemática. O princípio apolíneo está sendo experimentado nos mundos das belas aparências dos sonhos. A produção delas pelo homem é a pré-condição das belas artes, conforme o pensamento de Schopenhauer. Em Apolo Nietzsche encontra um deus que separa cuidadosamente aparência e realidade. Ele favorece os movimentos moderados e representa o respeito das limitações; Apolo faz a vida possível e é, para Nietzsche, o símbolo da confiança no principium individuationis. Com essa cogitação o autor retoma novamente um pensamento de Schopenhauer, que diz criticamente:

Tal como, em meio ao mar enfurecido que, ilimitado em todos os quadrantes, ergue e afunda vagalhões bramantes, um bar- 
queiro está sentado em seu bote, confiando na frágil embarcação; da mesma maneira, em meio a um mundo de tormentos, o homem individual permanece calmamente sentado, apoiado e confiante no principium individuationis (princípio de individuação). (Schopenhauer, 1818/1977:439)

Pois o simples, o transparente e o belo representados por Apolo pode sofrer uma brusca interrupção quando o homem sofre o assalto do horror, induzido através da dúvida súbita sobre as formas de conhecimento baseadas nas aparências; momento em que o princípio do fundamento, nihil est sine ratione, perde a sua validez. Nietzsche, até aqui ainda seguindo Schopenhauer, vai, agora, um passo além:

Se a esse terror acrescentarmos o delicioso êxtase que, à ruptura do principium individuationis, ascende do fundo mais íntimo do homem, sim, da natureza, ser-nos-á dado lançar um olhar à essência do dionisíaco, que é trazida nós, o mais de perto possível, pela analogia da embriaguez. Seja por influência da beberagem narcótica, da qual todos os povos e homens primitivos falam em seus hinos, ou com a poderosa aproximação da primavera a impregnar toda a natureza de alegria, despertem aqueles transportes dionisíacos, por cuja intensificação o subjetivo se esvanece em completo auto-esquecimento. [...] Sob a magia do dionisíaco torna a selar-se não apenas o laço de pessoa a pessoa, mas também a natureza alheada, inamistosa ou subjugada volta a celebrar a festa de reconciliação com seu filho perdido, o homem. [...] Se se transmuta em pintura o jubiloso hino beethoveniano à $<$ Alegria $>$ e se não refreia a força de imaginação, quando milhões de seres frementes se espojam no pó, então é possível acercar-se do dionisíaco. [...] Agora, graças ao evangelho da harmonia universal, cada qual se sente não só unificado, conciliado, fundido com seu próximo, mas um só, como se o véu de Maia tivesse sido rasgado e, reduzido a tiras, esvoaçasse diante do misterioso Uno-primordial. (Nietzsche, 1870/1992:30)

Os dois princípios, o apolíneo e o dionisíaco, não são feitos humanos. Para Nietzsche, emanam diretamente da natureza, são forças que não precisam do artista homem para se fazer presente, são forças irracionais que não têm fundamento passível a um entendimento racional. 
No início da Antigüidade grega, existiram duas formas de arte relacionadas a esses dois princípios. Posteriormente, assim relata Nietzsche, a tragédia ática sintetizou esses dois momentos. Agora a experiência dionisíaca, elementar e trágica, está sendo apresentada em uma forma apolínea. No auge da tragédia ática surge-lhe, paradoxalmente, um adversário potente, que é o principal responsável por sua decadência e por seu fim. Trata-se da filosofia grega a partir de Sócrates e Platão, valorizando cada vez mais o pensamento analítico. É ponto de partida do racionalismo europeu e do pensamento que chamamos de científico. Temos então uma nova dicotomia que contrapõe o dionisíaco ao socrático. Nesse conflito vê Nietzsche surgir um papel nobre da música, que seria a revitalização do princípio dionisíaco em detrimento do pensamento filosófico e científico rasos e certo moralismo cristão contemporâneo, com seu apequenamento do homem e enfraquecimento de suas forças vitais.

A doutrina do sobre-homem, apresentada no Zaratustra, não abre uma perspectiva de melhoria definitiva da condição humana. A tese do eterno retorno do mesmo erradica a esperança de encontro de um novo u topos e de uma compensação pela morte de Deus. Pois retorno do mesmo significa, também, o retorno do homem-rebanho com as suas qualidades duvidosas; é o retorno tanto do homem livre como do homem pequeno. As duas doutrinas, a do sobre-homem e a do eterno retorno, criam uma tensão quase insuportável no Zaratustra, pois a linha do tempo estendida para o futuro que é vinculado com a esperança da realização da vontade do poder, retorna formando um círculo temporal que anula qualquer perspectiva de um progresso histórico. Assim, Zaratustra lembra Sísifo obrigado a subir novamente, com sua pedra, ao topo da montanha, depois de já ter superado inúmeras vezes o mesmo caminho, com todas as dificuldades imagináveis. A pedra retorna ao pé da montanha e Sísifo volta para executar o veredicto do eterno retorno do mesmo, recomeça então seu caminho, subindo novamente com sua pesada carga. Por que devemos imaginar que Sísifo é um homem feliz, no momento em que desce a montanha e preparase para carregar novamente sua pedra? Ele é feliz porque valoriza o momento da descida sabendo que não tem salvação. É uma felicidade paradoxal que não conhece esperança e está nutrida por um desprezo do próprio sofrimento, é a felicidade que emana da resistência (Brüseke, 2002b). Não tem destino que o desprezo não supera, diz Nietzsche. Temos que imaginar Sísifo como um homem feliz, diz Camus. Os dois colocam a infinitude no momento finito agora vivido, inserindo esse momento no círculo de seu próprio retorno. 
Com a implosão da metafísica e a fuga dos deuses aumentou, para muitos pensadores do início do século XX, tanto a sensação de desamparo como a de falta de perspectiva histórica. A carga mística do momento agora vivido era sua conseqüência direta, pelo menos para aqueles que não esperavam o escaton do desenvolvimento da própria sociedade humana. $\mathrm{O}$ que restava dos grandes nexos destruídos era um Eu solitário e desilusionado, mas cheio de vontade de viver. Desespero e euforia iniciam uma estranha dança, cuja melodia fora esquecida desde as festas nas barulhentas noites durante a peste bubônica, no fim da idade média. A vida apresenta-se cada vez mais como o único valor ainda incontestado e as pessoas seguem o ímpeto de tentar esgotar o possível, buscando esquecer o além, juntamente com as falsas promessas de um Deus absconditus. O culto do momento agora vivido corresponde ao culto do mundo da vida, como se esse fosse a dimensão temporal e espacial do mesmo fenômeno. Pois a consciência da finitude da vida ameaça permanentemente a sociedade dos vivos. O outro lado do mundo da vida é o mundo da morte, fato negado de forma insistente pelos comunicadores da sociedade moderna.

O surgimento de uma mística sem Deus no contexto da crise da metafísica européia não se restringe ao campo filosófico stricto sensu, onde seus protagonistas freqüentemente rejeitam a denominação "mística" para caracterizar o seu pensar na margem do racionalismo ocidental. Podemos identificar, na própria teologia, uma redescoberta do momento irracional do sagrado já no início do século XX (Otto, 1917/1991), que se volta conseqüentemente contra a racionalização do "segredo da fé" e sua dissolução em uma filosofia moral ou política. Encontramos fortes reflexos disso nos teólogos contemporâneos como Dorothee Sölle (Sölle, 1999) e Leonardo Boff, depois de sua virada mística (Sell, 2004). Também no campo da literatura e da poesia não se calam as vozes que tematizam aquilo que a tecnicidade da sociedade moderna afugentou. De Hermann Hesse até Carlos Castañeda, de Rainer Maria Rilke até Gabriel Garcia Marques há uma corrente de autores que apontam, cada um à sua maneira, na direção do "místico" ou do "mágico". A amplitude e a complexidade de nossa temática impossibilita, obviamente, qualquer empreendimento capaz de reduzir essa complexidade a algo que ainda guarde a profundidade e a sutileza de seu objeto. Remetemos o leitor à leitura de algumas tentativas de aproximação do irracional como aquela feita por Hans Peter Dürr em sua antologia $O$ cientista e o irracional (Dürr, 1984), que reúne trabalhos da filosofia, antropologia e etnologia, além da psicologia. Indicamos também a coletânea organizada por Dietmar Kamper e Christoph Wulf $O$ sagrado - seus rastros pela modernidade 
(Kamper/Wulf, 1987) para aqueles que se interessem em estudar mais sistematicamente as irracionalidades na modernidade técnica. Chamamos atenção em especial para a necessidade de tratamento conceitual adequado quando se trata de fenômenos irracionais; neste contexto, a distinção entre magia e mística é certamente uma pré-condição para qualquer avanço de compreensão (Brüseke, 2004). A literatura esotérica que inunda as livrarias, nos últimos anos, mistura, em suas alusões místicas e mágicas do agrado do grande público, o joio com o trigo, em uma atitude representativa do espírito da nossa época, mais do que qualquer outra coisa. Em geral importa que o fenômeno romântico, historicamente distante, tenha se tornado mais acessível a uma interpretação madura; o mesmo não vale para a "mística sem Deus" e muito menos para a "escatologia política"; fenômenos praticamente contemporâneos, dos quais não temos distância necessária para uma análise sine ira et studio.

Aqui, no espaço restrito deste artigo, devemos ainda chamar atenção para mais um aspecto importante. Trata-se do perigo de um pensamento (político) que não se dá conta de sua carga mística.

\section{ESCATOLOGIA POLÍTICA}

O que significa escatologia? O escaton, a salvação, é o que move o judaísmo-cristianismo-islamismo, é sua essência e sua razão de ser. A escatologia é a doutrina das últimas coisas e do fim da história. Acreditase que, depois do juízo final e o fim do mundo, inicia-se uma nova vida que realizaria as esperanças religiosas. Os profetas do velho testamento vêem esse estado como reino messiânico, os cristãos, como reino de Deus, os muçulmanos, como paraíso. O caminho até aí é incomensurável. Não obstante: o reino está perto. Com os grandes profetas Moisés, Jesus e Maomé, começa, para as três religiões citadas, a história da salvação, que se torna também tema privilegiado de uma teologia da história. Como ler nas manifestações multifacetadas da criação os planos de Deus? Como ter notícia de sua sabedoria? Como saber de sua vontade, que trata de forma tão enigmática o destino do homem? O problema da escatologia sempre foi o problema do falso profeta, indicando caminhos errados, especulando, sem fundamento, sobre a vontade de Deus e prognosticando datas erradas para a finalização do processo da salvação. Sabemos que essas questões estão na raiz da divisão das grandes religiões monoteístas ocidentais e são, até hoje, fontes contínuas do surgimento de divergências. 
A história, que para muitos modernos é algo que acontece mas que não revela nenhum sentido fora daquele que os homens inventam, possui, para os cristãos, uma direção. Nesta perspectiva, estar no mundo é, no seu início, uma punição para a não-obediência a um mandamento de Deus; falta não cometida por mim mas herdada de meus ancestrais ou, em uma versão mais contemporânea, estar no mundo significa ser culpado; essa culpa e o pecado que acompanha o homem, renovando a culpa individualmente, exigem tanto penitência quanto esforços imediatos para que não se caia em tentação (e novamente se peque). Seria triste a perspectiva do homem se a graça divina não aliviasse sua sorte. Pois a saída definitiva deste vale de lágrimas somente é possível post mortem, quando ressurgem os mortos que, depois da avaliação dos seus méritos, participam na vida eterna ou não. A esperança dos cristãos direciona-se a este estado celeste e o agir no campo terreno somente tem significado enquanto mensurado pela vontade e as prescrições de Deus.

A tradição mística, dentro do próprio cristianismo, intermedia a experiência do divino no momento agora vivido, pois esses momentos são horas raras e curtas, como Bernhard de Clairvaux se expressa. O mainstream de uma teologia racionalizada e moralizada distancia a antecipação da união com Deus para aqueles tempos além do horizonte histórico. Esse tempo além do nosso horizonte é o alvo da esperança, é o locus do escaton prometido.

Na medida em que as ciências e a filosofia modernas avançaram sobre o pensamento religioso, a fé tornou-se opção individual e foi como tal tolerada enquanto se mantinha no âmbito privado. Publicamente o reino da razão - dividido em várias escolas e vertentes e sempre atento ao combate de um eventual retorno ao sagrado - inicia-se nos tempos do iluminismo. Marx era um dentre muitos desses intelectuais cujas obras, na primeira metade do século XIX, ainda estão marcadas pelo combate contra o imaginário religioso, como diriam os sociólogos contemporâneos.

Mas ninguém se livra tão fácilmente da situação histórica na qual foi lançado. Situação que é sempre moldada pela cultura de seu tempo e pelas respostas que os contemporâneos consideraram adequadas às velhas e às novas perguntas. A visão religiosa do mundo, no caso de Marx, não desaparece simplesmente quando o jovem Karl descobre seu ateísmo. O judaísmo-cristianismo é muito mais do que simplesmente a fé na constatação: Deus existe. Outros, como Weber, mostraram que mesmo o racionalismo ocidental recebeu fortes impulsos através da racionalização religiosa processada dentro do próprio cristianismo. Quando entendemos 
que racionalismo e teologia, razão e fé, não são antípodas tão assimétricos como afirma o senso comum, não nos surpreendemo quando estruturas do pensamento judaico-cristão aparecem de forma laicizada em seu adversário mais feroz: o materialismo histórico.

Toda filosofia do progresso do século XIX é marcada pela teleologia contida no judaísmo-cristianismo. Seu telos simplesmente tornou-se intramundano. Marx dividiu essa perspectiva com os progressistas e iluministas da época, participando desta maneira da estrutura teleológica da teologia cristã. Não viu somente direção - que também podia significar marchar na direção do apocalipse, da decadência (Spengler) ou da gaiola racional (Weber) - na história. Marx viu também a salvação. O escaton era a sociedade sem classes, onde todos os homens tornam-se irmãos, e o homem verdadeiro, com os seus cinco sentidos emancipados, surge das cinzas da revolução mundial. Marxismo é escatologia social e o marxismo pós-Marx, ao contrário de livrar-se dessa herança teológica, centrava sua propaganda na promessa dos novos tempos, além do horizonte do capitalismo. A escatologia do centro-marxismo, com Bebel e Kautsky, tornou a social-democracia marxista da Segunda Internacional algo estéril, incapaz de intervir na política do dia-a-dia. Esse fato atraiu críticas, tanto dos revisionistas, em torno de Eduard Bernstein, que queria abolir a tática do absoluto e realizar uma política de reformas concretas, como do grupo em torno de Rosa Luxemburgo que recomendava acelerar os passos na direção da terra prometida, da sociedade sem classes. Podemos dizer que a esquerda política ocidental sempre viveu essa tensão entre sua crença na possibilidade da "salvação social", que a condena ao imobilismo ou revolucionarismo, ou a tática dos passos reformistas e realistas, que freqüentemente fez desaparecer a diferença entre essa e as demais vertentes políticas (Groh, 1973; Schorske, 1955; Papcke, 1979).

Em Bloch (1875-1977), temos um representante do marxismo que, como nenhum outro, evidencia a escatologia nele embutida. Bloch a evidencia sem tomar distância crítica. Assume a escatologia e, mais do que isso, faz dela, em seu Princípio da esperança, o pilar da sua filosofia (Bloch, 1959/1970). O que interessa em nosso contexto é a referência da filosofia da esperança àquilo que não tem nome, aquilo que sempre não é, ainda. Concentramo-nos, junto a uma geração inteira de leitores políticos de Bloch, excessivamente no ainda, como se uma data ainda não tivesse sido alcançada. Pois o sem-nome da mística é sempre, também, um aindanão. Esse expressa uma saudade infinita e, também, a possibilidade de uma aproximação rara: quase, por pouco, ainda não. Na medida em que Bloch 
nega o real e o distancia do estado desejado, integra-se, sua obra, na tradição da filosofia mística.

Quando, para aqueles que não fecharam os olhos frente aos fatos indesejados, os rumos da experiência socialista na antiga União Soviética já eram mais do que evidentes, Bloch insistia em sua defesa. Eram os anos após o desastre da coletivização forçada do setor agrário, com milhões de mortos; os anos dos processos de Moscou, que levaram à eliminação física da antiga vanguarda bolchevique, dentre eles Bukarin, Zinoviev, Kamenev e muitos outros. Eram os anos da repressão de qualquer oposição, com deportações não somente de indivíduos rebeldes, mas de populações inteiras. Anos de chumbo que colocaram a primeira experiência socialista do mundo em um patamar de barbaridades somente alcançado por sua irmã inimiga, a Alemanha nacional-socialista. Bloch, delicado filósofo do aindanão e do andar reto resolve ignorar a dor dos outros e escreve:

Não sem razão vive no marxismo, além da, digamos, tolerância, que se expressa no reino da liberdade, também o, digamos, catedrálico que se expressa mesmo no reino da liberdade. Os caminhos até aí, pelo menos, não são liberais; eles são a conquista do poder no Estado, são disciplina, autoridade, planejamento central, linha geral, ortodoxia [...] exatamente a liberdade total: 'não se perca num amontoado de bel-prazeres arbitrários e no desespero sem substância, que se espera em seu fim, mas vença unicamente na vontade de ortodoxia' (Bloch apud Habermas, 1968:77)

Estas colocações levam Habermas a afirmar que Bloch daria à relação íntima da estratégia leninista com o poder somente uma camuflagem gótica. Na verdade, Bloch precisaria de décadas, mais precisamente até 1956, ano do levante popular na Hungria contra o regime comunista, para perder suas ilusões sobre o socialismo real. Precisaria de ainda mais cinco anos para se mudar, em 1961, da Alemanha Oriental socialista, que havia escolhido por razões de simpatia política, para Tübingen, na Alemanha Ocidental. Curioso é que Bloch foi recebido no Ocidente como símbolo da luta pela liberdade e de uma utopia humana da convivência social. Foi poupado de um debate embasado no politicamente correto, que teria descoberto um Bloch simpatizante do stalinismo até a morte do seu protagonista. Comparando o caso de Bloch com o de Heidegger, temos que admitir que Heidegger perdeu cedo a sua simpatia inicial pelo nacional-socialismo e nunca chegou a justificar os crimes do regime. Dizemos isso não para 
contribuir para um falso moralismo que, de segura distância histórica, mede o peso moral do outro, mas para criar incertezas produtivas neste juste milieu que caracteriza a cultura intelectual no início do século XXI. Além disso, já como fruto dessa incerteza, temos que nos perguntar porque a forma de pensar de Bloch e de Heidegger, representantes de duas vertentes influentes da filosofia contemporânea, não os protegeu contra o fracasso no plano político. Essa pergunta, dizemos isso mais uma vez, não visa aos aspectos morais da questão, mas ao conteúdo do pensar dos dois filósofos, que parece perder todos os parâmetros, quando se aproxima do mundo da política.

Levantamos então uma hipótese: tanto no caso da filosofia da esperança de Bloch, também chamada de ontologia do ainda-não, como no caso da filosofia do ser-aí de Heidegger, também chamada de ontologia fundamental, podemos identificar uma forte influência da filosofia mística, sem que os dois autores entendam suficientemente a importância e as consequiências dessa herança. Os dois autores não percebem como, em certos momentos, invertem a própria argumentação, transferindo a visão mística para um campo onde ela torna-se perigosa. Bloch, na sua relação com a experiência socialista, inverte o ainda-não da filosofia da esperança no já$e ́$ da ideologia soviética. Pois, em contato com o chão histórico presente, implode a esfera da esperança, deixando o amargo gosto da decepção. O ainda-não, sob ângulo místico, é condenado a manter distância do real e somente excepcionalmente toca naquilo que é.

Heidegger, quando escreveu o Ser e Tempo, não se deu conta da carga mística de seu pensamento; pelo contrário: defendeu-se mesmo contra críticos que tentaram desqualificar a ontologia fundamental como obscura, irracional e, inclusive, mística ou, no melhor dos casos, como onto-teologia. Sabemos que o filósofo mais tarde mudou alguns acentos de seu pensar, abrindo-se mais para aquilo que já estava veladamente presente em Ser e Tempo. Quando nessa obra apresentou o conceito de Entschlossenheit (estar decidido, decisão, destrancamento) não possuía um critério filosófico-político mínimo para sua direção e para o conteúdo daquele. "A questão do poder-ser todo é, portanto, uma questão de fato e existenciária, que a presença responde numa decisão" (Heidegger, 1927/1990:101). E mais adiante: "Mas não será que esta interpretação ontológica da existência aqui desenvolvida tem por base uma determinada concepção da existência própria (autêntica), isto é, um ideal do fato da presença (do ser-aí)? Sem dúvida" (Heidegger, 1927/1990:103).

A existência autêntica, ou própria, quando perde o contato com o unum necessarium perde também todos os critérios fundamentados. 
Querer ser autêntico sem fundamento remete o ser-aí à construção de um ideal de sua autenticidade. A falta de critérios necessários faz da escolha arbitrária uma consequiência lógica. $\mathrm{O}$ conceito de autenticidade em Heidegger, como o conceito do ainda-não em Bloch, tira sua força de fontes não reveladas pelo autor. Isso não poderia ser diferente, pois são fontes, por natureza, inacessíveis e além do horizonte teórico. A tentativa do contato direto faz implodir o que momentos antes ainda tinha força. Reduzir a autenticidade a uma concepção ou a um ideal do ser-aí, faz dela uma mera representação e como tal submetida à dinâmica do real e à possibilidade do fracasso. O ser-aí inautêntico, sob a perspectiva da Entschlossenheit pode se transformar assim no ser-aí alemão autêntico, pois absorve, num ato de decisão não fundamentada, isto é, completamente arbitrário, "um ideal". O curto-circuito na mente de Heidegger, em 1933, tem muito a ver com esse curto-circuito conceitual que vincula, via decisão, o impossível, isto é, o ser-aí autêntico singular com o impessoal (man) que é coletivo e, como Heidegger mostrou na mesma obra, sempre inautêncio. A queda no falatório era a consequiência imediata.

Com a corrosão dos valores tradicionais sob condições modernas, corrói-se também o herói de outrora. Restava a reminiscência tanto do heroísmo, como da ação de destaque. Dessas reminiscências, o que não foi abortado nas guerras industrializadas da modernidade técnica do século XX, que dispensavam cada vez mais as virtudes dos guerreiros e tornaram o herói algo obsoleto, sobreviveu numa estranha "mística" da decisão por uma determinada ação. A determinação dessa ação tinha como ponto de partida e fundamento somente a decisão solitária; era um sinal para os outros, uma expressão, mas não necessariamente uma execução dos valores dos outros. Contrariamente, surge na primeira metade do século XX uma "mística" da ação e também da arte, desvinculada do sentido social. Era o curto-circuito entre a decisão individual e a ação que fundamentasse um sentido exclusivamente compreensível para o próprio ator. Temos aí o nascimento do herói, que é herói somente para si mesmo. Jean-Paul Sartre e Albert Camus, como em toda literatura existencialista, exploraram bastante esse fenômeno. Podemos hoje nos perguntar se um determinado tipo de terrorista, este para cuja ação não cabe mais explicação ou justificativa e que não reclama, politicamente, a autoria desta, não possui afinidade psicológica com esse herói solitário. O "homem bomba" seria, nessa perspectiva, a realização, de forma mais radical, da "modernidade técnica" no plano individual.

Tanto o fascismo europeu, como outras diversas revoluções, aproveitaram até o limite desta tendência do homem moderno de procurar 
sentido naquilo que não tem sentido. Hipoteticamente diríamos: na medida em que a relação do homem com o valor numinoso está obscurecida e sua ação não se encontra mais integrada em uma prescrição cosmológica, esse tende a sacralizar ações solitárias e coletivas. Ele sacraliza o que não é sagrado e mistifica o que não é místico; a "mística" da ação decisiva dos fascistas e dos comunistas pode ser melhor compreendida quando colocada na perspectiva da decadência dos grandes sistemas metafísicos e teológicos.

\section{IRRACIONALIDADES NA MODERNIDADE TÉCNICA}

Os surtos irracionais do século $\mathrm{XX}$ podem ser interpretados como conseqüências da crise metafísica sem a qual a sociedade moderna não teria surgido. Mesmo na queda as grandezas absolutas revelam sua força e perturbam as esferas regidas, como Weber nos mostrou, pela racionalidade cognitiva ou pela racionalidade evaluativa. Parece que a ciência e a técnica, correspondendo à racionalidade cognitiva, e o sistema de direito moderno, correspondendo à racionalidade evaluativa, não suportam fortes doses de "racionalidade" expressiva e estética. Pois não se trata exclusivamente de uma mera interferência do "mundo da vida", expressiva e estética, nos grandes sistemas técnicos e jurídicos. Sentimos, mais uma vez, que o modelo das três esferas da sociedade, quando compreendidos em Weber e Habermas através de suas racionalidades distintas, perde sua força explicativa quando confrontado com a irracionalidade sui generis, presente de forma velada em todas as esferas. Essa irracionalidade fica ocultada porque o "preconceito racionalista" (Weber) da sociologia, tende a racionalizar seus objetos de estudo e marginaliza fenômenos fora do alcance de sua compreensão.

A ciência deseja somente saber como as coisas são e a técnica deseja mostrar como podemos fazer algo. Dessa maneira ficam, a ciência e a técnica, presas no plano ôntico e esquecem, como Heidegger mostrou, o próprio Ser (Heidegger, 1954/1994). A racionalidade cognitiva, presente nessa esfera científica e técnica, só pode ter acesso a fenômenos mutilados pelo próprio processo de investigação. Perguntas não permitidas pelos procedimentos científicos, no entanto, ficam no ar e descem à terra quando o cientista menos espera. A recusa (pertinente), por parte da ciência, de se aproximar das últimas questões que apontam na direção do fundamento do Ser frustra uma expectativa demasiadamente humana: querer saber de onde ele vem, onde está e para onde vai. 
Na medida em que a ciência e a técnica conseguem acessar as estruturas necessárias do Ser, as quais seguem suficientemente regras causais, torna-se o mundo passivo e manipulável pelos procedimentos produtivos e administrativos. Não obstante, a contingência do mundo objeto revela uma resistência oriunda do próprio Ser. Algo é como é, mas também poderia ser diferente. $\mathrm{Na}$ medida em que a técnica absorve (necessariamente) a contingência do Ser, do qual é mero derivado, torna-se o mundo das necessidades técnicas e científicas, de maneira sutil, altamente instável. A micro-física e a química sabem dessa instabilidade há décadas e expressam suas descobertas à sua maneira. Na sociologia, conceitos como risco (Beck, 1985), ambivalência (Bauman, 1999) ou contingência (Luhmann, 1992; Brüseke, 2002c) indicam o despertar do pensamento social para dimensões até então ignoradas ou marginalizadas. Não se trata somente da ampliação do horizonte dos procedimentos investigativos pela consciência da instabilidade e da relatividade; de forma curiosa e dramática, mostramse temas clássicos da condição humana, tidos como expurgados pelo pensamento moderno, como ainda presentes e influentes (Brüseke, 2003).

Parece que em suas fantasias e medos, esperanças e ansiedades, nos sentimentos inesperados e em sua memória mais profunda, o homem guarda a consciência de que tudo aquilo que é, não é tudo. O horror metafísico (Kolakowski) que a ciência expressa, tem como seu equivalente o horror de uma realidade desertificada pela própria consciência científica. O motivo romântico, contido na busca da flor azul, nos dá notícia de algo mais, ainda não alcançado. O século XX nos ensinou a tratar com mais propriedade a esperança de poder apanhar essa flor, de poder alcançar o escaton no campo histórico e nos colocou surpreendentemente frente ao velho problema do profeta falso. Os místicos sem Deus, por sua vez, não necessitam de esperança nem cultivam expectativas, preparam-se, em vez disso, para essas horas curtas e raras que podem revelar o sentido daquilo que é.

FRANZ JOSEF BRÜSEKE é professor de sociologia da Universidade Federal de Santa Catarina.

\section{REFERÊNCIAS BIBLIOGRÁFICAS}

BAUMAN, Zygmunt. Modernidade e Ambivalência. Rio de Janeiro: Jorge Zahar, 1999.

BECK, Ulrich. Die Risikogesellschaft. Frankfurt: Suhrkamp, 1986.

BLOCH, Ernst. Das Prinzip Hoffnung. Frankfurt: Suhrkamp, (1959) 1970.

BRÜSEKE, Franz Josef. A Técnica Moderna e o Retorno do Sagrado. Revista Tempo Social. v.2, n.1, p.209-230, 1999. 
BRÜSEKE, Franz Josef. A Modernidade Técnica. In: RBCS, v.17 n. 49. jun. 2002. p.135-144. São Paulo: ANPOCS-EDUSC. 2002a

BRÜSEKE, Franz Josef. Mística, Moral Social e a Ética da Resistência. In: Ethica - International Journal for Moral Philosophy. v.1. n.2. p.201-216, Florianópolis, 2002b.

BRÜSEKE, Franz Josef. A descoberta da contingência pela teoria social. In: Sociedade e Estado. Inovações no campo da metodologia das ciências sociais. V. XVII. N. 2. jul/dez 2002. Brasília: Depto. de Sociologia da UNB, pp.283-308, 2002c.

BRÜSEKE, Franz Josef. Paris na América. In: LEIS, Héctor; CALEB, F. Alves (orgs.). Condição Humana no Cone Sul. Florianópolis: Cidade Futura, pp.323-340. 2003

BRÜSEKE, Franz Josef. Mística, Magia e Técnica. In: Política e Sociedade: Revista de sociologia política. v.2. n. 4. Florianópolis: Programa de Pós-graduação em Sociologia Política, 2004.

DAWE, Alan. Teorias de Ação Social. In: Bottomore, Nisbet (orgs.). História da Análise Sociológica. Rio de Janeiro: Zahar, pp.475-546. (1978) 1980.

DÜRR, Hans Peter. Der Wissenschaftler und das Irrationale. Frankfurt: Syndikat, EVA, 1985.

GROH, Dieter. Negative Integration und revolutionärer Attentismus. Frankfurt, Berlin, Wien: Ullstein, 1973.

HABERMAS, Jürgen. Técnica e Ciência como Ideologia. Lisboa: Edições 70, (1968) 1994.

HABERMAS, Jürgen. Ein marxistischer Schelling. IN: Über Ernest Bloch. Frankfurt: Suhrkamp, 1968.

HEIDEGGER, Martin Die Frage nach der Technik. In: Heidegger, Martin: Vorträge und Aufsätze. Stuttgart: Neske, (1954) 1994.

HEIDEGGER, Martin. Ser e tempo. Petrópolis: Vozes, (1927) 1990.

KAMPER \& WULF (orgs.). Das Heilige: Seine Spur in der Moderne. Bodenheim, PhiloVerlag, 1997.

KLINGER, Cornelia. Flucht, Trost, Revolte. Die Moderne und ihre ästhetischen Gegenwelten. München, Wien: Carl Hanser Verlag, 1995.

KUNDERA, Milan. A Imortalidade. Rio de Janeiro: Editora Nova Fronteira, 1990.

LUHMANN, Niklas. Kontingenz als Eigenwert der modernen Gesellschaft. In: Beobachtungen der Moderne. Opladen: Westdeutscher Verlag, 1992.

MÜLLER-FUNK, Wolfgang. Die Farbe Blau.Untersuchungen zur Epistemologie des Romantischen. Wien: Turia \& Kant, 2000.

MUMFORD, Lewis. Mythos der Maschine. Frankfurt: Fischer, (1966) 1977.

NIETZSCHE, Friedrich $O$ nascimento da tragédia a partir do espírito da música. São Paulo: Companhia das Letras, (1870-71) 1992.

OTTO, Rudolf. O sagrado: um estudo do elemento não-racional na idéia do divino e sua relação com o racional. São Bernardo do Campo: Imprensa Metodista, (1917) 1991.

PAPCKE, Sven. Der Revisionismusstreit und die politische Theorie der Reform. Stuttgart, Berlin, Köln, Mainz: Kohlhammer, 1979.

SCHOPENHAUER, Arthur. Die Welt als Wille und Vorstellung. 10 v.,v.II., Zürich: Diogenes, (1818) 1977.

SCHORSKE, Carl E. German Social Democracy of 1905-1917. The Development of the Great Schism. Cambridge: Harvard University Press, 1955.

SELL, Carlos Eduardo. A Virada Mística: Subsídios para uma análise sociológica do discurso místico da teologia da libertação. UFSC, phil.diss., 2004.

SIMMEL, Georg. Grundfragen der Soziologie. Individuum und Gesellschaft. Berlin, (1917) 1970.

SÖLLE, Dorothee. Mystik und Widerstand. Hamburg: Hoffmann und Campe, 1999.

WEBER, Max. Wirtschaft und Gesellschaft. Tübingen: Mohr, (1922) 1985.

WITTGENSTEIN, Ludwig. Tractatus Logico-Philosophicus. São Paulo: Edusp, (1918) 1994. 